\title{
PKMS PENDAMPINGAN PENERAPAN MEDIA PEMBELAJARAN INOVATIF BERBASIS E-LEARNING UNTUK PENINGKATAN KOMPETENSI PADA GURU SMA N 1 ANJIR PASAR
}

\author{
Erfan Karyadiputra ${ }^{1}$, Iberahim ${ }^{2}$, Sari Kumala ${ }^{3}$ \\ Universitas Islam Kalimantan Muhammad Arsyad Al Banjari Banjarmasin ${ }^{1}$ \\ Erfantsy@gmail.com ${ }^{1}$ \\ Terrasin06@gmail.com ${ }^{2}$ \\ Sarikumalapgmi@gmail.com²
}

\begin{abstract}
The majority of teachers at Anjir 1 Public High School Market are skilled in using technology devices such as smartphones and computers. Supported by computer laboratory facilities and internet access in schools so that teachers should be able to make maximum use of these facilities in addition to learning support media as well as supporting the improvement of teacher competencies as professional educators. This community service activity aims to provide edmodo social media-based e-learning training that is very practical and easier to use for beginners so that in addition to the teacher having knowledge of e-learning as well as having the skills to support the learning process without limited space and time. The method used was in the form of an introduction to Edmodo's e-learning as well as the creation of an Edmodo account, followed by training in making digital exam questions using the Edmodo quiz facility involving students of Anjir Pasar 1 Public High School. The results of the activity found that the teacher can make digital exam questions with various types of questions such as true false, short answer, fill in the blank, multiple choice and matching.
\end{abstract}

Keywords: edmodo, e-learning, teacher, quiz

\begin{abstract}
ABSTRAK
Mayoritas Guru di SMA Negeri 1 Anjir Pasar sudah terampil dalam hal menggunakan perangkat teknologi seperti smartphone dan juga komputer. Ditunjang dengan fasilitas laboratorium komputer dan akses internet di Sekolah sehingga sudah seharusnya Guru dapat memanfaatkan fasilitas tersebut secara maksimal selain untuk media penunjang pembelajaran sekaligus penunjang untuk peningkatan kompetensi Guru sebagai tenaga pendidik profesional. Kegiatan pengabdian masyarakat ini bertujuan untuk memberikan pelatihan e-learning berbasis media sosial edmodo yang sangat praktis dan lebih mudah digunakan untuk pemula sehingga selain Guru memiliki pengetahuan tentang e-learning sekaligus juga memiliki keterampilan untuk menunjang proses belajar mengajar tanpa terbatas ruang dan waktu. Metode yang digunakan berupa presentasi pengenalan $e$ learning edmodo sekaligus pembuatan akun edmodo yang dilanjutkan dengan pelatihan pembuatan soal ujian digital menggunakan fasilitas quiz edmodo yang melibatkan siswa SMA Negeri 1 Anjir Pasar. Hasil kegiatan didapatkan guru dapat membuat soal ujian digital dengan berbagai tipe soal seperti true false (benar salah), short answer (jawaban pendek), fill in the blank (mengisi kolom kosong), multiple choice (pilihan ganda) dan matching (mencocokkan).
\end{abstract}

Kata Kunci: edmodo, e-learning, guru, quiz 


\section{PENDAHULUAN}

Mulai tahun ajaran 2018/2019 semua Sekolah termasuk SMA Negeri 1 Anjir Pasar diwajibkan menerapkan Kurikulum 2013 sehingga mengharuskan guru untuk mampu memperkenalkan dan melatih keterampilan dan keahlian sesuai perkembangan teknologi abad ke-21 kepada peserta didik [1]. Hal ini sesuai dengan yang tercantum dalam Undang-Undang Republik Indonesia No. 14 tahun 2005 tentang Guru dan Dosen yang berkaitan dengan beberapa kompetensi yang harus terus dikembangkan dan dimiliki sebagai seorang guru profesional, seperti tentang kemampuan dan keterampilan guru dalam memanfaatkan teknologi informasi dan komunikasi (TIK) dalam menunjang proses belajar dan mengajar [4]. Proses belajar mengajar di SMA Negeri 1 Anjir Pasar masih menerapkan sistem pembelajaran konvensional yang terbatas oleh waktu dan tempat. Proses belajar mengajar tersebut tentunya akan lebih maksimal jika dilengkapi dengan media pembelajaran berbasis komputer seperti e-learning. Melihat potensi dari mayoritas Guru di SMA Negeri 1 Anjir Pasar yang sudah cukup terampil dalam menggunakan perangkat teknologi informasi seperti smartphone dan juga media komputer serta didukung dengan adanya fasilitas penunjang di SMA Negeri 1 Anjir Pasar seperti akses internet dan laboratorium komputer, sehingga sudah seharusnya Guru dapat memanfaatkan fasilitas tersebut secara maksimal selain dijadikan untuk media penunjang pembelajaran sekaligus untuk media penunjang dalam meningkatkan kompetensi Guru sebagai tenaga pendidik profesional.

Belum maksimalnya potensi guru dalam memanfaatkan fasilitas teknologi informasi sebagai media pembelajaran inovatif seperti e-learning sejalan dengan data hasil survei yang dilaksanakan Asosiasi Penyelenggara Jasa Internet Indonesia (APJII) terkait penetrasi dan perilaku pengguna internet indonesia pada tahun 2017 yang menyatakan bahwa 89,35\% masyarakat indonesia menggunakan internet hanya untuk mengakses media sosial dan rendah dalam pemanfaatan internet sebagai sarana pendidikan [2]. Padahal kebanyakan pengguna internet di Indonesia berasal dari guru dan pelajar. Hal ini dimungkinkan karena masih kurangnya pengetahuan dan keterampilan dalam pemanfaatan media teknologi informasi seperti e-learning sebagai media pembelajaran inovatif untuk mendukung proses belajar mengajar. Kegiatan pengabdian masyarakat ini bertujuan untuk memberikan pelatihan e-learning berbasis media sosial edmodo yang sangat praktis dan lebih mudah digunakan untuk pemula sehingga selain Guru memiliki pengetahuan tentang e-learning sekaligus juga memiliki keterampilan untuk menunjang proses belajar mengajar tanpa terbatas ruang dan waktu [3]. Target kegiatan ini adalah Guru ditargetkan memiliki pengetahuan tentang e-learning edmodo dan dapat membuat soal ujian digital menggunakan fasilitas quiz edmodo yang melibatkan siswa SMA Negeri 1 Anjir Pasar. Luaran kegiatan berupa modul, video dokumentasi, artikel media massa online.

\section{METODE KEGIATAN}

Adapun metode yang akan diterapkan untuk penyelesaian permasalahan mitra di di SMA Negeri 1 Anjir Pasar, Desa Anjir Pasar Kota II terdiri dari beberapa tahapan dalam pelaksanaannya yaitu : 
1. Persiapan : pembuatan modul untuk guru SMA Negeri 1 Anjir Pasar, Desa Anjir Pasar Kota II untuk mempermudah pelatihan.

2. Ceramah/Presentasi/pemaparan materi: metode ini digunakan untuk menjelaskan dasar-dasar teori tentang e-learning secara umum dan edmodo secara khusus.

3. Demonstrasi dan diskusi: metode ini menjelaskan tentang cara penggunaan elearning edmodo dan fitur-fitur yang terdapat pada edmodo.

4. Praktik/workshop dan pendampingan: cara pembuatan e-learning edmodo sebagai sarana pendukung media pembelajaran guru SMA Negeri 1 Anjir Pasar. dan melakukan pendampingan pelatihan seperti membuat akun edmodo, membagi bahan ajar, membuat penugasan dan pembuatan soal ujian menggunakan menu quiz edmodo.

5. Evaluasi \& Monitoring untuk mengetahui sejauh mana kemampuan yang telah diserap peserta dalam menggunakan e-learning edmodo sebagai media pembelajaran sekaligus perbaikan kemampuan para mitra pasca evaluasi, dan melakukan monitoring penerapan pembelajaran e-learning oleh para peserta ke siswa.

Metode pelaksanaan kegiatan pelatihan ditunjukkan dalam gambar sebagai berikut:

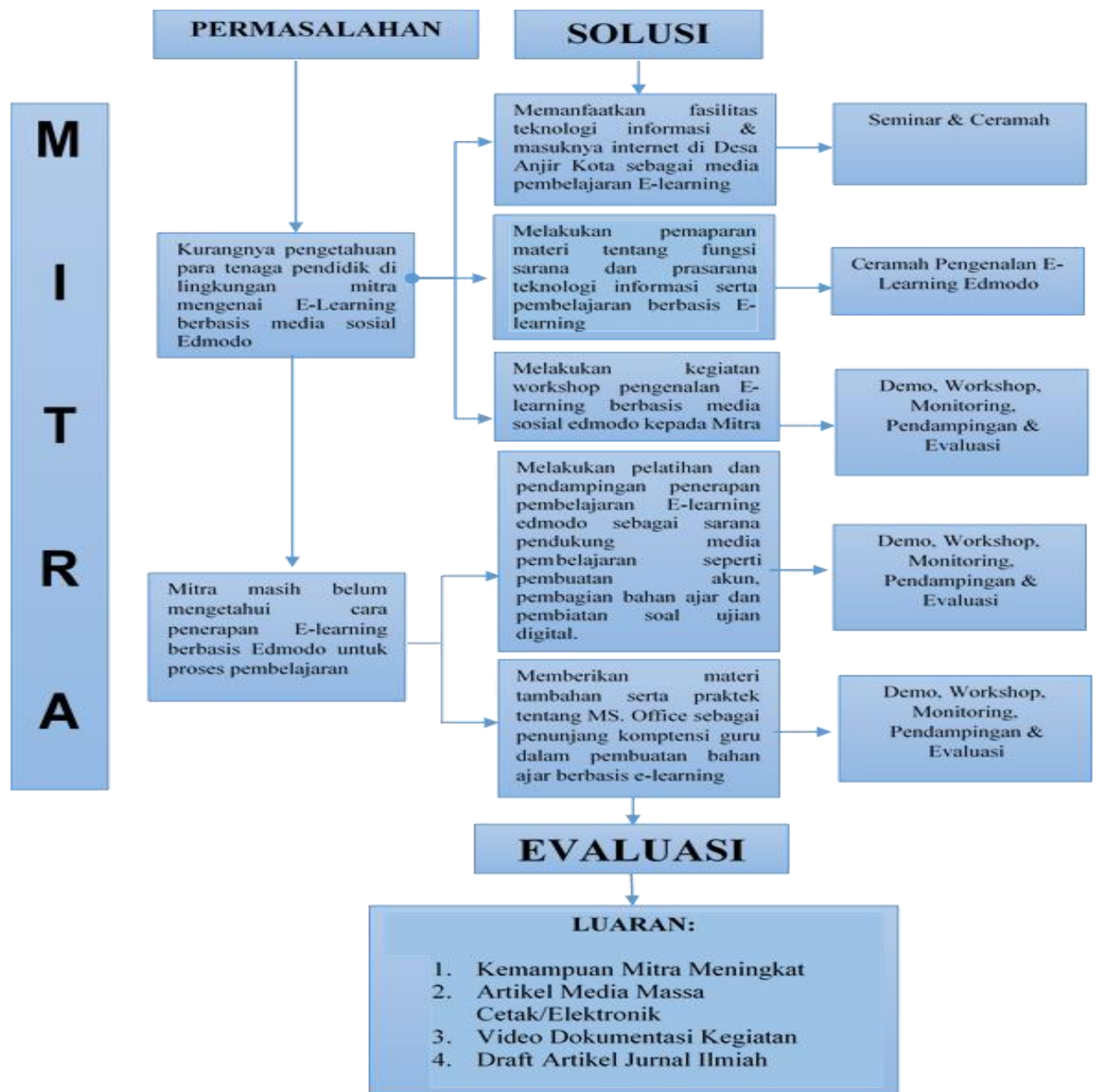

Gambar 1. Metode pelaksanaan kegiatan Pengabdian 


\section{HASIL DAN PEMBAHASAN}

Kegiatan Pengabdian dilaksanakan di SMA Negeri Anjir Pasar Desa Anjir Pasar Kota II, Kecamatan Anjir Pasar, Kabupaten Barito Kuala mulai tanggal 16 Juli 2019 sampai tanggal 18 Juli 2019. Hasil kegiatan secara garis besar mencakup beberapa komponen sebagai berikut:

1. Keberhasilan target jumlah peserta pelatihan, kegiatan pengabdian kepada masyarakat ini diikuti 38 peserta dari target 40 peserta.

2. Antusias peserta dalam mengikuti kegiatan

Selama proses pelatihan, peserta pengabdian terlibat aktif dalam mengikuti rangkaian kegiatan pelatihan seperti menerima paparan materi dengan baik, antusias dalam melakukan setiap sesi praktik pembelajaran e-learning dan keingin tahuan yang tinggi dengan aktif bertanya kepada tim pendamping kegiatan pengabdian kepada masyarakat.

3. Ketercapaian tujuan pengenalan materi dan pelatihan yakni kemampuan peserta dalam penguasaan materi, Berdasarkan beberapa metode yang sudah dijalankan dan hasil evaluasi freetest-posttest kemampuan peserta didapat hasil sebagai berikut:

Tabel 1. Evaluasi hasil free test dan post test peserta Pengabdian kepada Masyarakat

\begin{tabular}{|c|c|c|c|c|c|c|c|c|}
\hline \multirow{2}{*}{ No. } & \multirow{2}{*}{ Keterangan } & \multicolumn{2}{|c|}{ sebelum } & \multicolumn{2}{|c|}{ sesudah } & \multicolumn{2}{|c|}{ Tingkat Pengetahuan } & \multirow{2}{*}{$\begin{array}{l}\text { Peningkatan } \\
\text { Kompetensi }\end{array}$} \\
\hline & & Tidak & Ya & Tidak & Ya & sebelum & sesudah & \\
\hline 1 & $\begin{array}{l}\text { Apakah anda sudah menerapkan media pembelajaran } \\
\text { berbasis komputer dan internet }\end{array}$ & 16 & 22 & 3 & 35 & $58 \%$ & $93 \%$ & $35 \%$ \\
\hline 2 & Apakah anda tahu tentang media E-Learning & 17 & 21 & 2 & 36 & $56 \%$ & $96 \%$ & $40 \%$ \\
\hline 3 & Apakah anda sudah menerapkan media E-Learning di & 31 & 7 & 8 & 30 & $19 \%$ & $78 \%$ & $59 \%$ \\
\hline 4 & Apakah anda tahu tentang Edmodo sebagai media & 22 & 16 & 2 & 36 & $41 \%$ & $96 \%$ & $55 \%$ \\
\hline 5 & Apakah anda pernah menggunakan Edmodo & 32 & 6 & 10 & 28 & $15 \%$ & $74 \%$ & $59 \%$ \\
\hline 6 & Apakah anda bisa menggunakan Edmodo untuk & 32 & 6 & 6 & 32 & $15 \%$ & $85 \%$ & $70 \%$ \\
\hline 7 & Apakah anda bisa membuat tugas siswa menggunakan & 34 & 4 & 7 & 31 & $11 \%$ & $81 \%$ & $70 \%$ \\
\hline 8 & Apakah anda bisa membuat kuis dan soal ujian & 33 & 5 & 3 & 35 & $14 \%$ & $93 \%$ & $79 \%$ \\
\hline 9 & Apakah anda bisa membuat polling menggunakan & 35 & 3 & 7 & 31 & $7 \%$ & $81 \%$ & $74 \%$ \\
\hline 10 & Apakah anda tahu tentang microsoft office & 7 & 31 & 2 & 36 & $81 \%$ & $96 \%$ & $15 \%$ \\
\hline 11 & $\begin{array}{l}\text { Apakah anda pernah menggunakan microsoft office } \\
\text { untuk membantu dalam pembuatan materi bahan ajar }\end{array}$ & 7 & 31 & 2 & 36 & $81 \%$ & $96 \%$ & $15 \%$ \\
\hline 12 & $\begin{array}{l}\text { Apakah anda bisa menggunakan microsoft office untuk } \\
\text { membantu dalam pembuatan materi bahan ajar }\end{array}$ & 6 & 32 & 2 & 36 & $85 \%$ & $96 \%$ & $11 \%$ \\
\hline & RATA-RATA & 23 & 15 & 4 & 34 & $40 \%$ & $89 \%$ & $49 \%$ \\
\hline
\end{tabular}

Dari tabel di atas dapat dilihat bahwa mitra mengalami rata-rata progres peningkatkan pengetahuan dan keterampilan sebesar $49 \%$ dari kegiatan PKMS Pendampingan Penerapan Media Pembelajaran Inovatif Berbasis E-Learning Untuk Peningkatan Kompetensi Pada Guru SMA Negeri 1 Anjir Pasar. Rangkaian kegiatan dari PKMS pelatihan E-Learning berbasis media sosial Edmodo untuk transfer IPTEK ini dilakukan secara bertahap, dengan uraian antara lain: ceramah penyajian materi, workshop/praktek tentang pengenalan dan pentingnya ELearning dalam menunjang proses pembelajaran. 
Adapun materi penggunaan media E-Learning Edmodo yang dipaparkan antara lain:

Tabel 2. Materi Pelatihan Pengabdian kepada Masyarakat

\begin{tabular}{|c|c|}
\hline Materi Utama & Materi Penunjang \\
\hline Pengenalan metode E-Learning untuk proses pembelajaran. & \multirow{9}{*}{$\begin{array}{l}\text { Memberikan materi } \\
\text { tambahan serta } \\
\text { praktek tentang } \\
M S \text {. Office sebagai } \\
\text { penunjang } \\
\text { komptensi guru } \\
\text { dalam pembuatan } \\
\text { bahan ajar berbasis } \\
\text { e-learning }\end{array}$} \\
\hline Pengenalan beberapa media E-Learning. & \\
\hline Pembuatan akun Edmodo sebagai guru. & \\
\hline 4. Pengaturan akun Edmodo. & \\
\hline Pembuatan kelas pada media sosial Edmodo. & \\
\hline 6. Penggunaan fitur Notes. & \\
\hline 7. Penggunaan dan setting fitur Assigments. & \\
\hline $\begin{array}{l}\text { 8. Penggunaan quiz pada Edmodo } \\
\text { (Tipe Multiple Choice, True False, Short Answere, } \\
\text { Matching serta Fill in the blank). }\end{array}$ & \\
\hline 9. Penggunaan fitur pooling dan Edmodo Planner. & \\
\hline
\end{tabular}

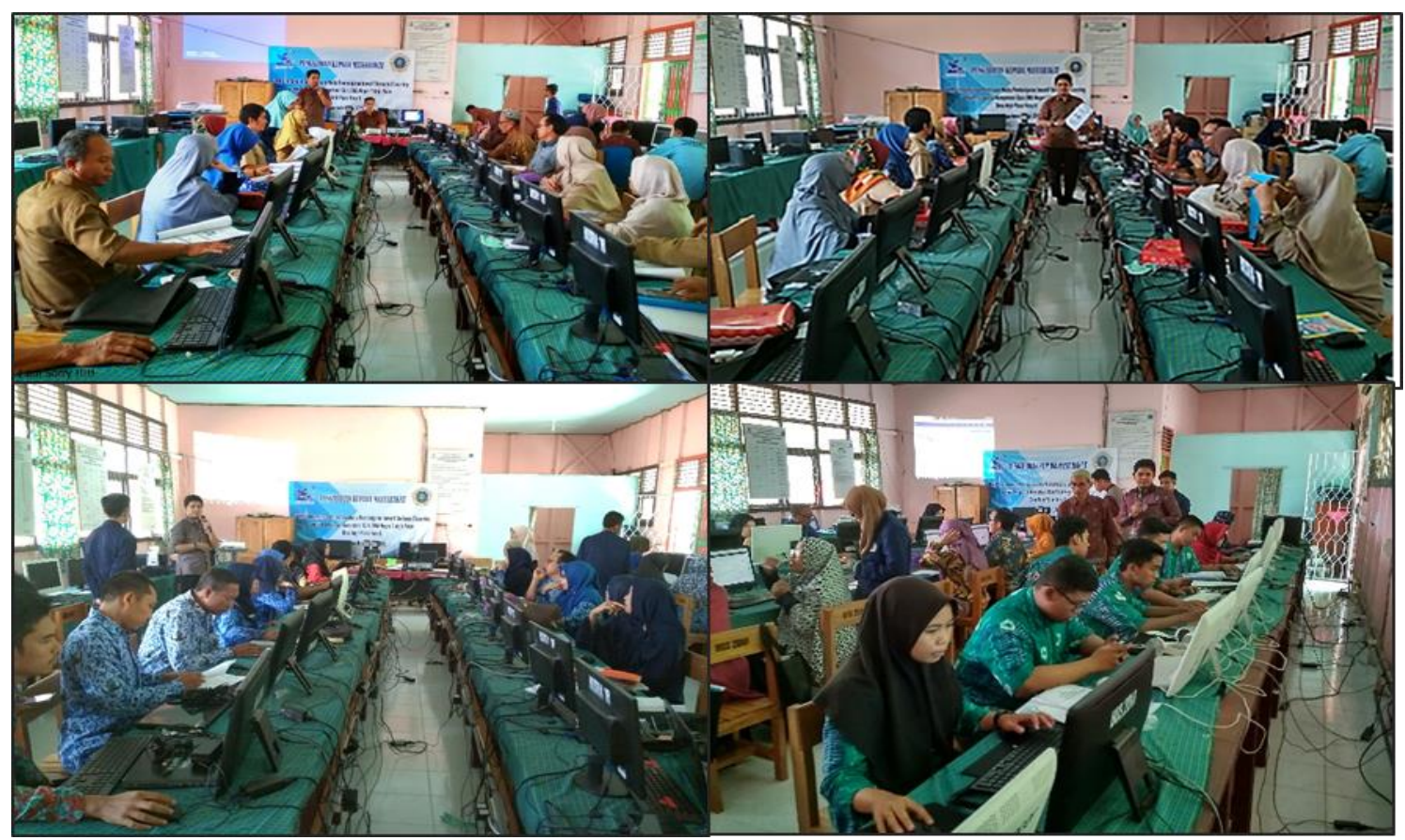

Gambar 2. Pemberian Materi Pelatihan

Dari hasil evaluasi awal free test dan evalusi akhir post test kemampuan peserta secara umum dapat disimpulkan telah berhasil dilaksanakan. Adapun instrumen utama pengukur keberhasilan kegiatan PKMS ini yakni hasil evaluasi kemampuan mitra sebelum free test dan sesudah post test kegiatan dapat dilihat dalam diagram sebagai berikut: 


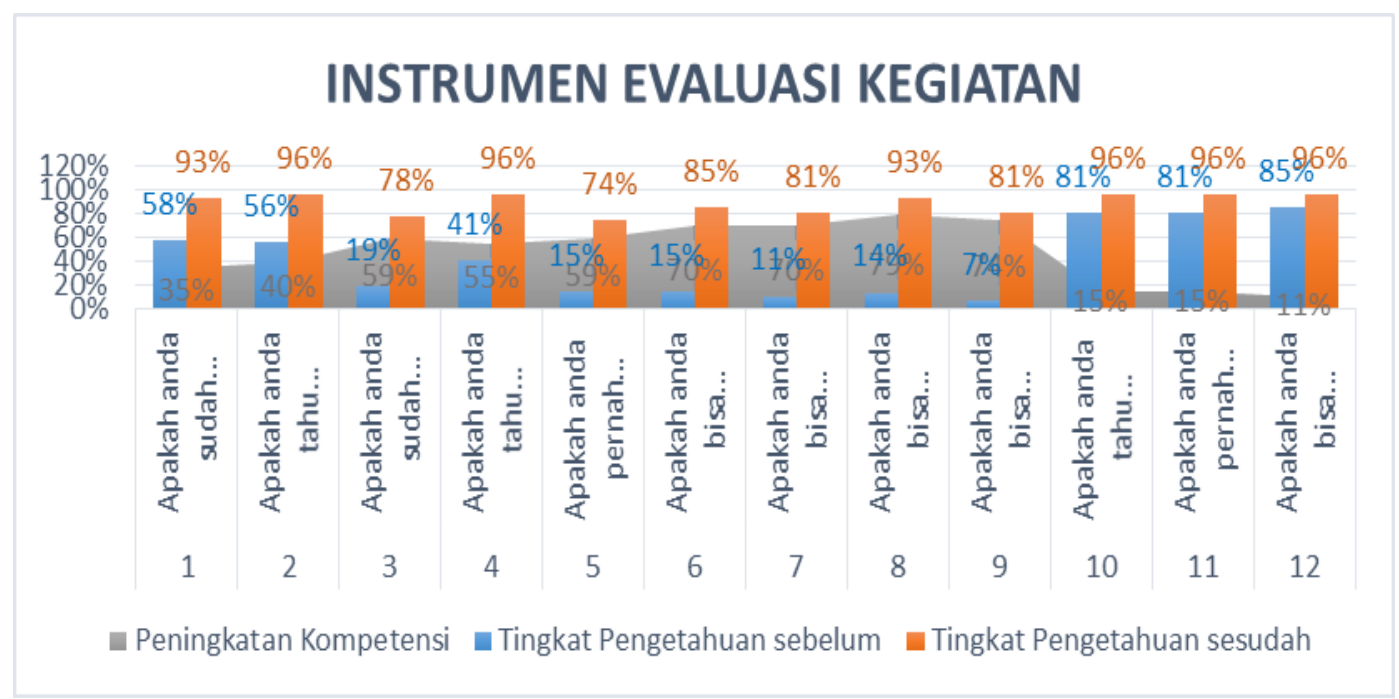

Gambar 3. Instrumen Evaluasi Kegiatan Pengabdian Kepada Masyarakat

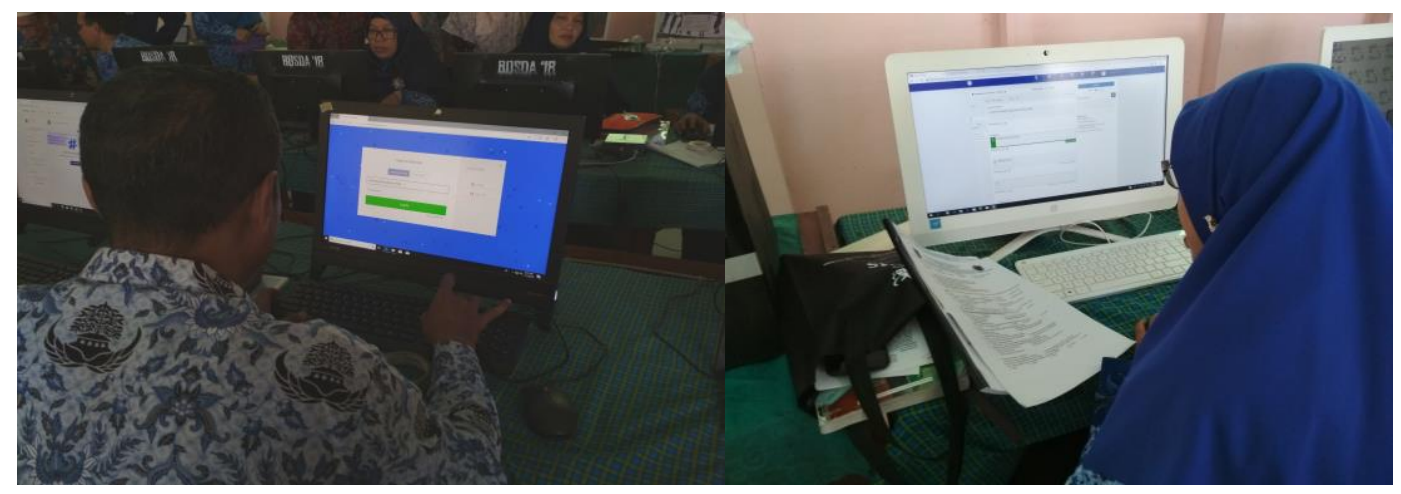

Gambar 4. Pendampingan Penilaian Soal Hasil Ujian Bersama Guru \& Siswa

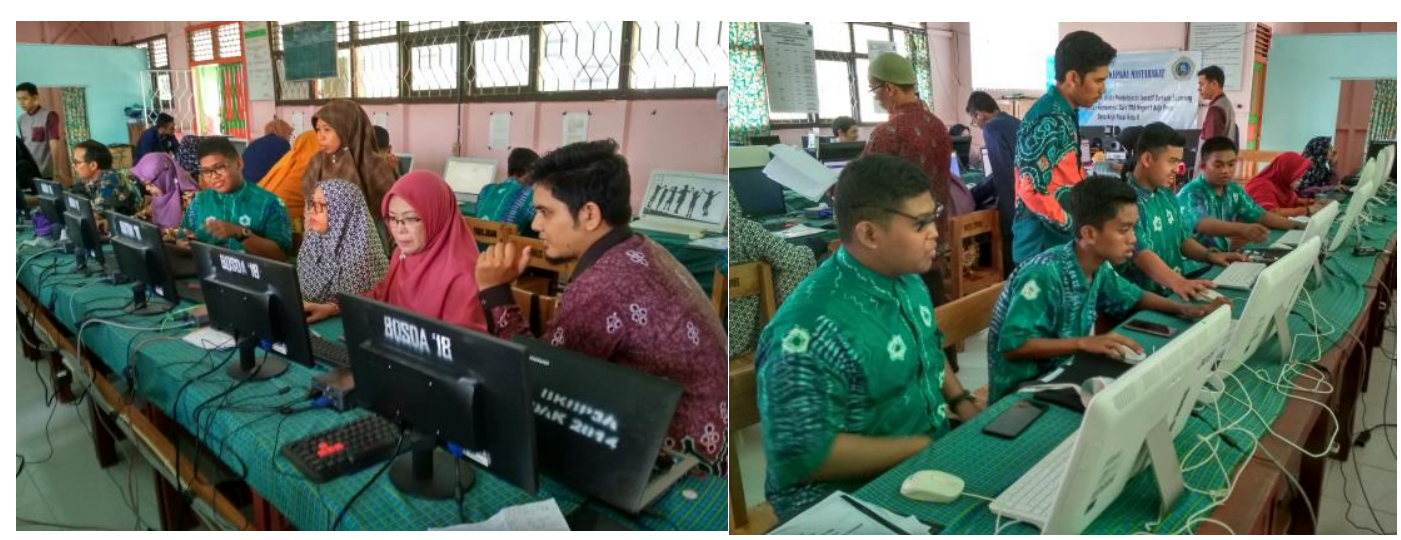

Gambar 5. Pelatihan Membuat Akun dan Membuat Soal Ujian Edmodo 


\section{KESIMPULAN}

Berdasarkan hasil evaluasi, Kegiatan PKMS Pendampingan Penerapan Media Pembelajaran Inovatif Berbasis E-Learning Untuk Peningkatan Kompetensi Pada Guru SMA Negeri 1 Anjir Pasar ini secara umum dapat disimpulkan telah berhasil dilaksanakan. Adapun instrumen pengukur keberhasilan kegiatan PKMS ini antara lain:

1. Antusias yang tinggi dari para peserta pelatihan, berupa partisipasi dari jumlah peserta yang mengikuti pelatihan.

2. Bertambahnya pengetahuan dan pemahaman peserta tentang e-learning sebagai media pembelajaran inovatif terutama e-learning berbasis media sosial edmodo

3. Meningkatnya keterampilan peserta dalam menerapkan e-learning edmodo sebagai media pendukung pembelajaran seperti pembagian bahan ajar, pembuatan tugas dan penggunaan fasilitas quis edmodo untuk pembuatan soal ujian

Berdasarkan hasil evaluasi di lapangan terdapat saran untuk kegiatan pengabdian ini yakni perlu adanya keberlanjutan pelaksanaan program dimasa yang akan datang. Program Pengabdian selanjutkan diharapkan mampu meningkatkan kompetensi para guru dalam hal pelatihan pembelajaran berbasis multimedia untuk meningkatkan minat belajar siswa. Dengan demikian proses peningkatan kompetensi guru dalam hal teknologi informasi dapat berkelanjutan mengikuti kemajuan IPTEK yang semakin berkembang.

\section{UCAPAN TERIMA KASIH}

Ucapan terima kasih disampaikan kepada Direktorat Riset dan Pengabdian Masyarakat (DRPM) Kementerian Riset, Teknologi, Dan Pendidikan Tinggi yang telah membiayai pelaksanaan kegiatan pengabdian masyarakat Program Kemitraan Masyarakat Stimulus (PKMS) ini.

\section{DAFTAR PUSTAKA}

R. Naimi, 2018, Mulai Agustus Tahun Ajaran Baru 2018/2019 Semua Sekolah Wajib Pakai Kurikulum 2013, viewed 01 Juli 2018, <https://banjarmasin.tribunnews.com>

APJII, 2017, Hasil Survei Penetrasi dan Perilaku Pengguna Internet Indonesia 2017, 19 Februari 2017. <https://apjii.or.id>

Umaroh, S., 2012. Penerapan Project Based Learning menggunakan Microblogging Edmodo untuk Meningkatkan Prestasi Belajar Siswa. Skripsi UPI: Bandung.

Nomor, U.U.R.I., 14. tahun 2005 tentang Guru dan Dosen. 